\title{
Arsenic Exposure: Mechanisms of Action and Related Health Effects
}

\author{
Bilal Ahmad Tantry ${ }^{1,2^{*}}$, Divya Shrivastava ${ }^{2}$, Ibrahim Taher ${ }^{1}$ and Mudasar Nabi Tantry ${ }^{3}$
}

${ }^{1}$ Department of Microbiology, College of Medicine, Aljouf University, Saudi Arabia

${ }^{2}$ School of Life Sciences, Jaipur National University, Jaipur, India

${ }^{3}$ Department of Clinical Biochemistry, Kashmir University, India

\begin{abstract}
Arsenic represents a natural drinking water contaminant that can deteriorate health due to its extreme toxic nature. Infant mortality, neuropathies, liver disease, cancer, eye diseases, cardiovascular disease and different skin alterations can stem from chronic arsenic exposure. The predominant species of arsenic comprise of arsenite and arsenate. Arsenite is more toxic in nature as compared to arsenate. Arsenic pollution is mainly caused by natural process such as weathering of rocks and minerals followed by leaching and industrial activities that lead to contamination of soil and groundwater. The WHO guideline permits the maximum limit of arsenic as $10 \mu \mathrm{g} / \mathrm{L}$ in drinking water. This review provides a comprehensive overview on arsenic mode of action, its sources and health related effects. The effect of toxicity, biomarkers of arsenic toxicity and the mechanism of arsenic dangers on humans are also discussed.
\end{abstract}

Keywords: Arsenic health effects; Arsenic; Cancer; Arsenic metabolism; Chronic arsenic exposure; Drinking water

\section{Introduction}

For many centuries, Arsenic (As) has almost exclusively been connected with deliberate poisoning, but in the contemporary world, it has largely contributed to escalating environmental pollution. The widespread anthropogenic use of pesticides containing arsenic can adversely affect human health. In addition, the activities that involves mining and burning of coal, thereby releasing it in the air has received pivotal attention [1]. Arsenic differs in its form when food and drinking water are concerned. In food, arsenic is found in both organic and inorganic form, depending on the kind of food, whereas, arsenic is present in inorganic form (either as $\mathrm{As}^{\mathrm{III}}$ or $\mathrm{As}^{\mathrm{V}}$ ) in drinking water [2]. Groundwater usually contains arsenic as detected in 70 countries worldwide that has affected 140 million people. Most of the affected people live in Asia (such as Bangladesh, India) who have been affected with concentration levels higher than the WHO drinking water arsenic value of $10 \mu \mathrm{g} / \mathrm{L}$ as well as the national regulatory standards (e.g., 50 $\mu \mathrm{g} / \mathrm{L}$ in India and Bangladesh) $[3,4]$.

Arsenic contamination prevalent in groundwater often stems from geological sources and its consumption can cause chronic health disorders in numerous affected regions across the globe [5]. In Asia, arsenic found in groundwater is considered as the largest environmental health disaster that aims to threaten at least 100 million people in the Bengal Basin of Bangladesh and West Bengal. Arsenic exposure and consumption has been affecting India with cancer disease and other Asrelated ailments [6]. Arsenic is the 52nd out of 92 elements that is heavily found in earth's crust and has a concentration of 1.8 parts per million. This poisonous element occurs naturally in numerous minerals such as arsenopyrite, tennantite (copper arsenic sulfide) and realgar (arsenic sulfide). In soils, mostly the inorganic forms of arsenic are found such as $\mathrm{As}^{\mathrm{III}}$ (arsenite) and AsV (arsenate) [7,8]. Monomethylarsonic acid (MMAA), Methylated species, trimethylarsine oxide (TMAO) and dimethylarsinic acid (DMAA) are vastly present in biomass, but soils also incorporate them [1]. In addition, $\mathrm{As}^{\mathrm{V}}$ and $\mathrm{As}^{\mathrm{III}}$ can be evaporated at regular temperature for transforming into arsine, MMAA changing to tomonomethylarsine [9], TMAO transforming to trimethylarsine (TMA) and DMAA taking shape of dimethylarsine (DMA) [10].

Different soil parameters are likely to affect the toxicity and bioavailability of arsenic prevalent in soil. Soil parameters such as redox potential, $\mathrm{pH}$, soil and site hydrology can highly influence the toxicity of arsenic. In addition, microbial and plant components can affect the arsenic absorption. The above-mentioned parameters can affect the behavior of soil colloids and absorption capacity, thereby changing the bioavailability and solubility of arsenic [11-13]. In natural ecosystem settings, the chemical processes can play a pivotal role in controlling the arsenic exposure and mobility. However, there are increased chances that microbial metal reduction can also play an essential role in mobilizing toxic metals that can have disastrous effects on living beings' health. Microbial reduction of $\mathrm{As}^{\mathrm{v}}$ and more poisonous and mobile As ${ }^{\mathrm{III}}$ species can take place through respiration processes $[14,15]$.

Numerous bacteria contain the $\mathrm{As}^{\mathrm{V}}$-reductase gene that is involved in $\mathrm{As}^{\mathrm{V}}$ reduction [16], only few microorganisms which have the capability to respire $\mathrm{As}^{\mathrm{V}}$ have been secluded [17]. The AsV-respiring bacteria are likely to use various electron donors such as hydrogen and acetate; and can be of different types ranging from mesophiles to extremophiles [17]. Through laboratory studies, it has been determined that microbial phenomena that plays an essential role in reducing and mobilizing $A s^{\mathrm{V}}$ are more rapid as compared to inorganic chemical changes [18]. Laboratory researches revealed that these microorganisms can significantly contribute in As cycling in the earth crust $[14,18,19]$.

\section{Arsenic Mechanism of Action and Related Health Effects}

\section{Arsenic metabolism}

Arsenic can enter human body by drinking impure water and can act as deterrent to secure health. Hence, arsenic is vulnerable to human health and can cause cancer also. This issue is becoming a

*Corresponding author: Bilal Ahmad Tantry, Department of Microbiology, College of Medicine, Aljouf University, Saudi Arabia, Tel: 966506281724 E-mail: batantry@ju.edu.sa

Received August 17, 2015; Accepted October 25, 2015; Published October 28 2015

Citation: Tantry BA, Shrivastava D, Taher I, Tantry MN (2015) Arsenic Exposure: Mechanisms of Action and Related Health Effects. J Environ Anal Toxicol 5: 327. doi:10.4172/2161-0525.1000327

Copyright: @ 2015 Tantry BA, et al. This is an open-access article distributed under the terms of the Creative Commons Attribution License, which permits unrestricted use, distribution, and reproduction in any medium, provided the original author and source are credited. 
significant health concern across the globe [20]. According to a current comprehensive study conducted by the genome-wide association, particular genetic differences connected with vulnerability of forming skin lesions were identified. It was also discovered that the arsenic metabolism differs in each individual [21]. Different methods have been developed that can benefit mammals in detoxifying inorganic AS. Although numerous organisms possess the capability to change inorganic As into organic arsenic, but liver arsenite methyltransferases is absent or deficient in certain mammals such as chimpanzee, guinea pig, marmoset monkey and various South American monkeys [22].

There is a major confusion regarding the appropriateness of methylation as the primary way to detoxify inorganic As ${ }^{\mathrm{III}}$. Various tissues prevalent in the methylation process of enzymes are diverse in nature. In case of mouse, its testis is the most active part as compared to kidney, lung and liver [22,23]. Hence, this depicts that inorganic $\mathrm{As}^{\mathrm{III}}$ methylation process is not only reliant on liver, as understood in the past. Application of the product formed from reaction of a metal ion DIMAVAL (2, 3-dimercapto- 1-propanesulfonic acid) on 24 subjects in Chile played a significant role in changing DMA and MMA excretion in the urine. Hence, urine was affected by the use of chemical. Before DIMAVAL, the MMA excretion accounted for 14\% but MMA escalated to $42 \%$ of total As excretion after oral administration [22]. Researchers also discussed the differences in As metabolism found in humans due to the fact that all groups of humans were aware of methylate inorganic As [24].

Researchers suggest that the significant factors that can influence As methylation will be required in future. It must be taken into consideration that the patterns of As organic compounds in urine substantially differ from one individual to others. For instance, a small number of females in the Argentina Andes excrete small quantity of MMA in their urine [25]. Methylation holds immense significance in relation to As metabolism phenomena, methylation reactions that consists of interactions, selenium and inhibitors, this encouraged the discussion of As interactions in the studies. This is significant because As and selenium differ in numerous biologic systems. Moreover, numerous investigators do not consider that the different ways prevalent for mammals to engage in methylation process and they ignore the multifaceted interactions and relationships of these ways. Research depicts that different human responses have been observed to As exposure in South America [25]. The differences in human responses when exposed to AS have been increasing with the passage of time and might require new techniques and different approaches of analysis. A significant technique is to use pharmacokinetic (PK) approaches on which intake of As (V), As (III), DMA, MMA and any combination of these four substances in the human body is based [26]. These approaches are used to illuminate tissues of As species that function according to change in dose and time. The PK approach has been used as model for testing a receptor-mediated system for inorganic As. Moreover, the researchers focused on examining the potential significance of complexity and differences in As toxicology. It must be taken into consideration that the typical molecular biology and biochemical research studies about how As metabolism takes place are insufficient.

\section{Molecular processes of cancer formation}

Arsenic is considered as an element that can cause cancer in skin, bladder, lung, liver, and kidney. Research has revealed that arsenicrelated deaths can result from lung cancer [27]. Arsenic is not involved in causing gene mutations, thereby indirectly reacting with DNA (Figure 1). Numerous mechanisms have been established by which

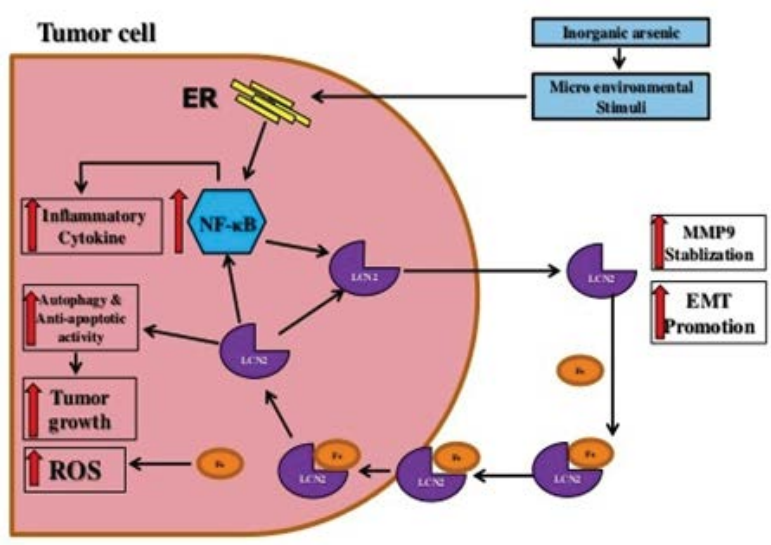

Figure 1: Long term exposure to inorganic arsenic associated with DNA hypermethylation which leads to the downregulation of tumor suppressor genes.

arsenical compounds form tumors such as genotoxic can damage, oxidative stress and abnormalities in chromosomes [20]. People that possess p53 Arg/Arg genotype were less prone to inorganic arsenic and had increased amount of DMA. This implies that they were better able to undergo arsenic methylation process and reduce toxification [28]. Arsenite cannot impede any DNA repair enzyme, but it is probable that arsenite can obstruct the management of DNA repair process as compared to the repair substances [29]. Aneuploidy can be subjected to arsenite. Arsenite is different from spindle poisons because arsenite does not hinder to form spindle fiber; instead arsenite is involved in deranging the spindle equipment through facilitating polymerization of microtubule.

While working on a latest cell conversion arrangement (by experimenting on rat liver epithelial cell line TRL 1215), it was discovered that global DNA epigenetic changes, initiation of the proto-oncogene c-myc and reduced DNA methylated enzymes activity significantly influenced the persistent exposure to harmful arsenite conversion. The findings of the research study explained that arsenite can act as a cancer-causing element through inducing hypomethylation of DNA, thereby causing abnormal gene characteristics [30]. Another experiment that was conducted on $\mathrm{p} 53$ promoter in human lung A549 carcinoma cells showed that opposite results can appear on DNA methylation process through arsenite. A long-standing subjection to arsenite escalated $\mathrm{CpG}$ methylation within the $\mathrm{p} 53$ promoter that had increased chances of blocking transcription of the significant $p 53$ gene [31]. The p53 gene is considered as an important gene that subdues tumors and its protein product are vital in controlling the apoptosis, cell cycle and DNA repair. After 24 hours of conducting treatment with arsenite, the researchers observed significant changes in the $\mathrm{p} 53$ gene and the cell cycle in three cell lines. An effect of transfecting mutant p53 gene with cells depicted that the cells are more sensitive to arsenite.

\section{Arsenic related health consequences}

Childhood cancer: In theory, there is inadequate information related to arsenic subjection in drinking water that can cause the ailment of childhood cancer [32] described that arsenic can increase the chances of lymphoblastic leukemia risk; however the arsenic amount in usual drinking water was very low that deterred increase chances of Leukemia [33]. Increased levels of arsenic in Drinking water can cause bladder cancer bladder, skin cancer and can adversely affect the 
intellectual ability of children [34]. Childhood cancer frequency rates in Nevada were observed at increased water levels in the range of 35-90 $\mu \mathrm{g} / \mathrm{L}$. The relative risk estimate was 1.25 (CI 0.91-1.69) for childhood cancer and 1.37 (CI: 0.92-1.83) for the vulnerable ailment of leukemia.

young children aged under 20 years, who were exposed to high arsenic content $(\mathrm{RR}=10.6,95 \% \mathrm{CI} 2.9-39.2, p<0.001)$ in drinking water became victims of mortality subject to liver cancer [35]. The affected children died prior to 1980 and the reason for their death could not be proved by any medical records nor was it confirmed that these children died because of increased exposure to arsenic in drinking water [33]. In short, it can be epitomized that past research studies rejects the notion that deaths are increasingly caused due to childhood cancers, but through one study, increased relative risks for liver cancer have been found that are subject to increased arsenic substances in drinking water.

Decreased infant weight and increased infant mortality: Arsenic exposure has a strong connection with increased infant death incidences and; according to certain research studies arsenic exposure can result in stillbirth and abortion [36], as well as decreased weight of new born babies [37]. Early-life arsenic exposure can highly weaken the neurological capabilities of children such as verbal communication abilities, IQ levels of girls are inversely related with arsenic exposure $[38,39]$. Birth weight differs according to countries such as decreased weight of new born babies resulting from low exposure to arsenic have been discovered Chile (28), Taiwan (86) and Bangladesh (28). In Chile, the decrease in average weight of new born babies estimation accounted for $57 \mathrm{~g}$ and $30 \mathrm{~g}$ in Taiwan. In Bangladesh, regression coefficients helped in understanding that an increase in $1 \mu \mathrm{g} / \mathrm{g}$ in hair arsenic can reduce babies weight upto $19.5 \mathrm{~g}$ [40-42].

Adverse effects on alterations: When arsenic is consumed by the human body, it causes pigmentation changes in the skin of the trunk and limbs and nodular keratosis on the soles and palms [41]. Through analyzing several epidemiological studies related to skin lesions, it was discovered that most people suffering from skin lesions had consumed drinking water containing arsenic content of $>100 \mu \mathrm{g} / \mathrm{L}$, although lesions have been reported at arsenic concentrations of $<50$ $\mu \mathrm{g} / \mathrm{L}$. In most populations involved in consuming drinking water and encountering arsenic water issues, lesions were considered as the first symptom to identify the issue. According to a current report from the Health Effects of Arsenic Longitudinal Study (HEALS) prospective study, the vulnerable risk of subjecting to skin lesions was not reduced after decrease in arsenic exposure for up to several years. Hence, lesions are likely to occur on skin several years after exposure reduces [43]. In 1960 's, it was discovered that there is a high propensity of skin lesions to emerge due to arsenic content in drinking water in Taiwan [44] and the same results were revealed in India and West Bengal in the 1980s [45].

Human prostate cancer: In the late 1980s, the first evidence that inorganic arsenic was highly correlated with human prostate cancer discovered from Taiwan [46]. This was a follow-up study that concentrated on dose-response relationships between arsenic and cancer in a population exposed to high levels of arsenic in the drinking water from local artesian wells. The population studied belonged to the area of endemic "black foot" disease prevailing in southwest Taiwan, a disease that involved the peripheral vascular dysfunction likely due to arsenic exposure [47]. Although the original study had not looked at cancer of the prostate [47], the subsequent study identified a noteworthy correlation between arsenic vulnerability and prostate cancer mortality in this population [46].
Arsenic-induced diseases affecting eyes: A methodical survey had been conducted for determining whether chronic arsenic ingestion can result in any particular eye problems. It was discovered that exposed individuals suffered from watering, irritation, and redness in both eyes. Few populations also reported that they were suffering from conjunctivitis due to chronic arsenic ingestion [48]. A skilled ophthalmologist carefully screened the participants for conjunctivitis disease and related eye diseases. Some cases associated with having record of mucopurulent discharge (characteristic of bacterial conjunctivitis), photophobia and extreme watering (characteristic of viral conjunctivitis), and severe itching and ropy discharge (characteristic of allergic conjunctivitis) were exempted. Other symptoms due to arsenic exposure incorporated the pigmentation in the sclera, pinguecula, pterygium and conjunctival congestion.

Cardiovascular ailment: Epidemiological studies conducted across different parts of the world relating to high levels of arsenic $(>300 \mu \mathrm{g} / \mathrm{l})$ in ground water have discovered that arsenic exposure is strongly correlated with increased risks of cardiovascular ailments, carotid atherosclerosis [49], ischemic heart disease and mortality due to vascular disease [50]. The distinct association with manifestations of generalized arteriosclerosis supplies certainty on causality. However, the underlying approaches have not been well-defined. Large-scale prospective studies that have been using pertinent biomarkers can help in identifying pathways by which arsenic develops and stimulates vascular disease [51]. According to several studies, it has been revealed that arsenic present in drinking water can develop cardiovascular diseases, especially in Taiwan $[49,52,53]$. In China and Bangladesh, it was reported that electrocardiogram changes in exposed populations can result in escalating risk of arrhythmia, mortality, cerebrovascular and cardiovascular disease $[47,54]$.

Evidence related to increased disease risks caused by arsenic methylation: Arsenic can cause health ramifications that differ from one individual to another. In addition, it must be understood that several factors are involved such as genetics, age of exposure, diet and smoking habits that can influence the extent of seriousness of the health diseases. Past research studies have discovered that arsenic metabolism differs among individuals and this can cause significant differences in the severity of health diseases generating from arsenic metabolism. The main method that facilitates inorganic form of arsenic metabolism in human bodies is methylation [55]. As the Arsenic enters the body, the methylation process starts that methylates InAs to monomethylarsonic acid (MMA5), which transforms into monomethylarsonous acid (MMA3). MMA3 takes shape of dimethylarsinic acid (DMA5) that consequently turns into dimethylarsinous acid (DMA3).

It must be understood that in human bodies, this process remains incomplete, thereby arsenic remaining as InAs and MMA. In the case of humans, arsenic elimination takes place through urinary excretion, and internal metabolism is reflected through the various components of InAs, DMA and MMA in urine [56,57]. The portion of MMA, InAs and DMA found in human urine are usually utilized as biomarkers of the extent to which humans are involved in methylating absorbed InAs. Absorbed InAs involves around 10\% to $15 \%$ MMA, $10 \%$ to $20 \%$ InAs and $60 \%$ to $75 \%$ DMA, although there are abundant situations in which there is a large differences in individuals' ingested InAs [58]. A significant pathway used for facilitating detoxification is called as methylation of InAs. The reason is that the methylated enzymes that are frequently gauged in urine samples-DMA and MMA are more frequently excreted and considered as less toxic in nature as compared to InAs $[59,60]$. 
DMA3 and MMA3 are unbalanced in human urine and hence have been gauged in few research studies related to mechanisms of human body. However, it must be taken into consideration that MMA3 contains an increased poisonous content in vitro as compared to its pentavalent type. In addition, MMA3 is considered as even more poisonous than trivalent InAs [61,62]. From these results, it can be stated that MMA3 can be the most poisonous specie of absorbed arsenic.

Presence of arsenic - resulting in genotoxicity, oxidative stress and DNA disruption: Many experimental observations determine that genotoxicity caused by arsenic refers to the process of generating ROS during the biotransformation phase of arsenic. When ROS are produced, it can facilitate DNA adducts; this can break DNA strand, thereby causing chromosomal abnormality [63]. Arsenic act as an impediment on individual's health and can cause serious ailments such as oxidative stress, genotoxicity and ineffective DNA repair capacity. Numerous research studies conducted in Latin America have proved that abnormality in chromosomes were more ubiquitous in Mexican people due to high arsenic exposure (As: $0.39 \mathrm{mg} / \mathrm{L}$ ) than those with low arsenic exposure (0.019-0.026 mg/L) [64]. Likewise, a significant increase $(\mathrm{P}<0.001)$ in sister chromatid exchange was detected in Argentina's population where arsenic content in drinking water was $0.13 \mathrm{mg} / \mathrm{L}$ [65]. The studies conducted in Chile revealed that arsenic emerging by evaluating micronucleus induction from occupational and environmental exposure could result in genotoxic effects $[66,67]$. Prevalence of As significantly damaged DNA and this resulted in increased level of tumor suppressor protein p53 for individuals who were highly exposed to vulnerable arsenic content [68-70]. It was observed in Mexico that improving any genotoxicity of as would have adverse effects on DNA repair competencies.

\section{Conclusions}

It can be epitomized that the numerous individuals in Asia are subject to the damaging arsenic toxification and related diseases that can cause mortality. It is recommended that researches related to minimize and mitigate arsenic in most affected places must be conducted in future. This will improve public health. Moreover, findings resulting from future genetic epidemiologic and molecular studies can help in determining the potential implications for preventing and curing arsenic-related toxicities across the world.

\section{References}

1. Leonard A (1991) Arsenic In: Merian E (Eds) Metals and their compounds in the environment. Weinheim: VCH 751-772.

2. European Food Safety Authority Scientific Opinion on Arsenic in Food (2009) EFSA J 7: 60-71.

3. Ahmed KM, Bhattacharya P, Hasan MA, Akhter SH, Alam SMM, et al. (2004) Arsenic enrichment in groundwater of the alluvial aquifers in Bangladesh: an overview. Appl Geochem 19: 181-200.

4. Mukherjee A, Sengupta MK, Hossain MA, Ahamed S, Das B, et al. (2006) Arsenic contamination in groundwater: a global perspective with emphasis on the Asian scenario. J Health Popul Nutr 24: 142-163.

5. Smedley PL, Kinniburgh DG (2002) A review of the source, behaviour and distribution of arsenic in natural waters. Appl Geochem 17: 517-568.

6. Mukherjee $A B$, Bhattacharya $P$ (2001) Arsenic in groundwater in the Bengal Delta Plain: Slow poisoning in Bangladesh. Environ Rev 9: 189-200.

7. Masscheleyn PH, Delaune RD, Patrick WH (1991) Effect of redox potentia and $\mathrm{pH}$ on arsenic speciation and solubility in a contaminated soil. Environ Sci Technol 25: 1414-1419.

8. Smith E, Naidu R, Alston AM (1998) Arsenic in the soil environment: A review. Adv Agron 64: 149-195.
9. Rahman MM, Mukherjee D, Sengupta MK, Chowdhury UK, Lodh DC, et al. (2002) Effectiveness and reliability of arsenic field testing kits: are the million dollar screening projects effective or not? Environ Sci Technol 36: 5385-5394.

10. Cullen WR, Reimer KJ (1989) Environmental Arsenic Chemistry. Chem Rev 89: 713-764.

11. Goldberg S, Glaubig RA (1988) Anion sorption on calcareous, montmorillonitic soil arsenic. Soil Sci Soc Am J 52: 1297-1300.

12. Livesey NT, Huang PM (1981) Adsorption of arsenate by soils and its relation to selected chemical-properties and anions. Soil Science 131: 88-94.

13. Roy WR, Hassett JJ, Griffin RA (1986) Competitive coefficients for the adsorption of arsenate, molybdate and phosphate mixtures by soils. Soil Sci Soc Am J 50: 1176-1182.

14. Ahmann D, Roberts AL, Krumholz LR, Morel FM (1994) Microbe grows by reducing arsenic. Nature 371: 750.

15. Cervantes C, Ji G, Ramírez JL, Silver S (1994) Resistance to arsenic compounds in microorganisms. FEMS Microbiol Rev 15: 355-367.

16. Santini JM, Stolz JF (2004) Prokaryote arsenate and selenate reduction. In Nakano MM and Zuber P eds. Strict and facultative anaerobes: medical and environmental importance: Horizon Scientific Press 239-250.

17. Oremland RS, Stolz JF (2003) The ecology of arsenic. Science 300: 939-944.

18. Jones CA, Langner HW, Anderson K, McDermott TR, Inskeep WP (2000) Rates of microbially mediated arsenate reduction and solubilization. Soil Sci Soc Am J 64: 600-608

19. Islam FS, Gault AG, Boothman C, Polya DA, Charnock JM, et al. (2004) Role of metal-reducing bacteria in arsenic release from Bengal delta sediments. Nature 430: 68-71.

20. Ren X, McHale CM, Skibola CF, Smith AH, Smith MT, et al. (2011) An emerging role for epigenetic dysregulation in arsenic toxicity and carcinogenesis. Environ Health Perspect 119: 11-19.

21. Pierce BL, Kibriya MG, Tong L, Jasmine F, Argos M, et al. (2012) Genome-wide association study identifies chromosome 10q24.32 variants associated with arsenic metabolism and toxicity phenotypes in Bangladesh. PLoS Genet 10 e1002522.

22. Aposhian HV, Arroyo A, Cebrian ME, Del Razo LM, Hurlbut KM, et al (1997) DMPS-arsenic challenge test. 1: Increased urinary excretion of monomethylarsonic acid in humans given dimercapto propane sulfonate. Pharma col Exp Ther 282: 192-200

23. Healy SM, Casarez EA, Ayala-Fierro F, Aposhian H (1998) Enzymatic methylation of arsenic compounds. V. Arsenite methyltransferase activity in tissues of mice. Toxicol Appl Pharmacol 148: 65-70.

24. Vahter M (1994) Species differences in the metabolism of arsenic. In: Arsenic Exposure and Health Chappell WR, Abernathy CO, Cothern CR (eds) Northwood, UK: Science and Technology Letters 171-179.

25. Vahter M, Concha G, Nermell B, Nilsson R, Dulout F, et al. (1995) A unique metabolism of inorganic arsenic in native Andean women. Eur J Pharmacol 293: 455-462.

26. Mann S, Droz PO, Vahter M (1996) A physiologically based pharmacokinetic model for arsenic exposure. II. Validation and application in humans. Toxicol Appl Pharmacol 140: 471-486.

27. IARC (International Agency for Research on Cancer) (2012) A Review of Human Carcinogens: Arsenic, Metals, Fibers, and Dusts. Lyon: World Health Organization Press.

28. Huang CY, Su CT, Chu JS, Huang SP, Pu YS, et al. (2011) The polymorphisms of P53 codon 72 and MDM2 SNP309 and renal cell carcinoma risk in a low arsenic exposure area. Toxicol Appl Pharmacol 257: 349-355.

29. Rossman TG (1998) Molecular and genetic toxicology of arsenic. In: Environmental Toxicology: Current Developments Rose J (Eds) Amsterdam: Gordon and Breach Publishers 171-187.

30. Zhao CQ, Young MR, Diwan BA, Coogan TP, Waalkes MP (1997) Association of arsenic-induced malignant transformation with DNA hypomethylation and aberrant gene expression. Proc Natl Acad Sci USA 94: 10907-10912.

31. Mass MJ, Wang L (1997) Arsenic alters cytosine methylation patterns of the promoter of the tumor suppressor gene p53 in human lung cells: a model for a mechanism of carcinogenesis. Mutat Res 386: 263-277. 
Citation: Tantry BA, Shrivastava D, Taher I, Tantry MN (2015) Arsenic Exposure: Mechanisms of Action and Related Health Effects. J Environ Anal Toxicol 5: 327. doi:10.4172/2161-0525.1000327

Page 5 of 5

32. Infante-Rivard C, Olson E, Jacques L, Ayotte P (2001) Drinking water contaminants and childhood leukemia. Epidemiology 12: 13-19.

33. Moore LE, Lu M, Smith AH (2002) Childhood cancer incidence and arsenic exposure in drinking water in Nevada. Arch Environ Health 57: 201-206.

34. Wasserman GA, Liu X, Parvez F, Factor-Litvak P, Ahsan H, et al. (2011) Arsenic and manganese exposure and children's intellectual function. Neurotoxicology 32: $450-457$.

35. Liaw J, Marshall G, Yuan Y, Ferreccio C, Steinmaus C, et al. (2008) Increased childhood liver cancer mortality and arsenic in drinking water in northern Chile. Cancer Epidemiol Biomarkers Prev 17: 1982-1987.

36. Rahman A, Persson LÅ, Nermell B, El Arifeen S, Ekström EC, et al. (2010) Arsenic exposure and risk of spontaneous abortion, stillbirth, and infant mortality. Epidemiology 21: 797-804.

37. Rahman A, Vahter M, Smith AH, Nermell B, Yunus M, et al. (2009) Arsenic exposure during pregnancy and size at birth: a prospective cohort study in Bangladesh. Am J Epidemiol 169: 304-312.

38. Parvez F, Wasserman GA, Factor-Litvak P, Liu X, Slavkovich V, et al. (2011) Arsenic exposure and motor function among children in Bangladesh. Environ Health Perspect 119: 1665-1670.

39. Hamadani JD, Tofail F, Nermell B, Gardner R, Shiraji S, et al. (2011) Critical windows of exposure for arsenic-associated impairment of cognitive function in pre-school girls and boys: a population-based cohort study. Int J Epidemiol 40: $1593-1604$

40. Hopenhayn-Rich C, Browning SR, Hertz-Picciotto I, Ferreccio C, Peralta C, et al. (2000) Chronic arsenic exposure and risk of infant mortality in two areas of Chile. Environ Health Perspect 108: 667-673.

41. Rahman A, Vahter M, Ekström EC, Rahman M, Golam Mustafa AH, et al. (2007) Association of arsenic exposure during pregnancy with fetal loss and infant death: a cohort study in Bangladesh. Am J Epidemiol 165: 1389-1396.

42. von Ehrenstein OS, Guha Mazumder DN, Hira-Smith M, Ghosh N, Yuan Y, et al. (2006) Pregnancy outcomes, infant mortality, and arsenic in drinking water in West Bengal, India. Am J Epidemiol 163: 662-669.

43. Argos M, Kalra T, Pierce BL, Chen Y, Parvez F, et al. (2011) A prospective study of arsenic exposure from drinking water and incidence of skin lesions in Bangladesh. Am J Epidemiol 174: 185-194.

44. Chakraborty AK, Saha KC (1987) Arsenical dermatosis from tubewell water in West Bengal. Indian J Med Res 85: 326-334

45. Tseng WP, Chu HM, How SW, Fong JM, Lin CS, et al. (1968) Prevalence of skin cancer in an endemic area of chronic arsenicism in Taiwan. J Natl Cance Inst 40: 453-463.

46. Chen CJ, Kuo TL, Wu MM (1988) Arsenic and cancers. Lancet 1: 414-415.

47. Chen CJ, Chuang YC, Lin TM, Wu HY (1985) Malignant neoplasms among residents of a blackfoot disease-endemic area in Taiwan: high-arsenic artesian well water and cancers. Cancer Res 45: 5895-5899.

48. Baidya K, Raj A, Mondal L, Bhaduri G, Todani A (2006) Persistent conjunctivitis associated with drinking arsenic-contaminated water. J Ocul Pharmacol The 22: $208-211$

49. Wang CH, Hsiao CK, Chen CL, Hsu LI, Chiou HY, et al. (2007) A review of the epidemiologic literature on the role of environmental arsenic exposure and cardiovascular diseases. Toxicol Appl Pharmacol 222: 315-326.

50. Tseng CH, Tai TY, Chong CK, Tseng CP, Lai MS, et al. (2000) Long-term arsenic exposure and incidence of non-insulin-dependent diabetes mellitus: a cohort study in arseniasis-hyperendemic villages in Taiwan. Environ Health Perspect 108: 847-851.

51. States JC, Barchowsky A, Cartwright IL, Reichard JF, Futscher BW (2011) Arsenic toxicology: translating between experimental models and human pathology. Environ Health Perspect 119: 1356-1363.

52. Navas-Acien A, Sharrett AR, Silbergeld EK, Schwartz BS, Nachman KE, et al. (2005) Arsenic exposure and cardiovascular disease: a systematic review of the epidemiologic evidence. Am J Epidemiol 162: 1037-1049.

53. Engel RR, Hopenhayn-Rich C, Receveur O, Smith AH (1994) Vascular effects of chronic arsenic exposure: a review. Epidemiol Rev 16: 184-209.

54. Kwok RK, Mendola P, Liu ZY, Savitz DA, Heiss G, et al. (2007) Drinking water arsenic exposure and blood pressure in healthy women of reproductive age in Inner Mongolia, China. Toxicol Appl Pharmacol 222: 337-343.
55. Vahter M (2002) Mechanisms of arsenic biotransformation. Toxicology 181 182: $211-217$.

56. Marafante E, Vahter M, Envall J (1985) The role of the methylation in the detoxication of arsenate in the rabbit. Chem Biol Interact 56: 225-238.

57. Marafante E, Vahter M (1984) The effect of methyltransferase inhibition on the metabolism of [74As]arsenite in mice and rabbits. Chem Biol Interact 50: 49-57.

58. Hopenhayn-Rich C, Smith AH, Goeden HM (1993) Human studies do not support the methylation threshold hypothesis for the toxicity of inorganic arsenic. Environ Res 60: 161-177.

59. Buchet JP, Lauwerys R, Roels $H$ (1981) Comparison of the urinary excretion of arsenic metabolites after a single oral dose of sodium arsenite monomethylarsonate, or dimethylarsinate in man. Int Arch Occup Environ Health 48: 71-79.

60. Gebel TW (2002) Arsenic methylation is a process of detoxification through accelerated excretion. Int J Hyg Environ Health 205: 505-508.

61. Mass MJ, Tennant A, Roop BC, Cullen WR, Styblo M, et al. (2001) Methylated trivalent arsenic species are genotoxic. Chem Res Toxicol 14: 355-361.

62. Petrick JS, Ayala-Fierro F, Cullen WR, Carter DE, Vasken Aposhian H (2000) Monomethylarsonous acid (MMA(III)) is more toxic than arsenite in Chang human hepatocytes. Toxicol Appl Pharmacol 163: 203-207.

63. Jomova K, Jenisova Z, Feszterova M, Baros S, Liska J, et al. (2011) Arsenic: toxicity, oxidative stress and human disease. J Appl Toxicol 31: 95-107.

64. Ostrosky-Wegman P, Gonsebatt ME, Montero R, Vega L, Barba H, et al. (1991) Lymphocyte proliferation kinetics and genotoxic findings in a pilot study on individuals chronically exposed to arsenic in Mexico. Mutat Res 250: 477-482.

65. Lerda D (1994) Sister-chromatid exchange (SCE) among individuals chronically exposed to arsenic in drinking water. Mutat Res 312: 111-120.

66. Martínez V, Creus A, Venegas W, Arroyo A, Beck JP, et al. (2004) Evaluation of micronucleus induction in a Chilean population environmentally exposed to arsenic. Mutat Res 564: 65-74.

67. Paiva L, Marcos R, Creus A, Coggan M, Oakley AJ, et al. (2008) Polymorphism of glutathione transferase Omega 1 in a population exposed to a high environmental arsenic burden. Pharmacogenet Genomics 18: 1-10.

68. Salazar AM, Calderón-Aranda E, Cebrián ME, Sordo M, Bendesky A, et al (2004) p53 expression in circulating lymphocytes of non-melanoma skin cance patients from an arsenic contaminated region in Mexico. A pilot study. Mol Cell Biochem 255: 25-31.

69. Andrew AS, Burgess JL, Meza MM, Demidenko E, Waugh MG, et al. (2006 Arsenic exposure is associated with decreased DNA repair in vitro and in individuals exposed to drinking water arsenic. Environ Health Perspect 114: 1193-1198.

70. Xing C, Toshifumi W, Yoshio S, Katsuyoshi H, Seishiro H (2006) Chronic Ora Exposure to Inorganic Arsenate Interferes with Methylation Status of p16INK4a and RASSF1A and Induces Lung Cancer in A/J Mice. Toxicological sci 91 372-381. 